\section{Cash crisis threatens to close Mexico's leading university}

Sir-Academic staff at the National Autonomous University of Mexico (UNAM), the most important university in the country, have been on strike for more than 160 days in protest at the government's plan to increase student fees. It has been a devastating experience.

Two hundred professors have been dismissed and there is a threat to close UNAM. It could be declared bankrupt so that the government would be able to cancel labour contracts without having to pay compensation. But it is vital that UNAM remains open. It educates more students than any other university in Mexico, many of them from other countries in Latin America. UNAM's 1,100 research scientists conduct $60 \%$ of the research done in Mexico.

Non-academic employees are also threatening to strike at the end of October unless they receive an absurd pay rise of $40 \%$. This would spell the end of UNAM.

Mexico has an external debt of almost US $\$ 200$ billion, and the World Bank has imposed on the government tough economic measures which result in undesirable social and cultural effects. UNAM's financial requirements are now seen as a heavyburden on the government's budget and President Ernesto Zedillo seems intent on cutting such "excessive expenses". Yet all the economic problems of our country are a direct result of the actions of dishonest administrations over the years, who have been blind to the needs of science and technology.

UNAM is being seen as a business, which is an absurd mistake. Mexico has a small community of just 6,000 full-time researchers, 4,500 dedicated to natural sciences and engineering. Research receives far too little financial support.

UNAM has always played an outstanding role in science and it is imperative that this should be promoted and preserved above any other political consideration. Alejandro Cuevas-Sosa

Centro de Prevención y Tratamiento de la Violencia Sexual e Intrafamiliar, San Lorenzo 203, Col. Del Valle 03100, Mexico, DF

\section{How to bring collections data into the net}

Sir-Electronic access to natural history collections data will enable biodiversity to be mapped with other parameters, improving science and environmental management. At least 10 major initiatives desire networked access to these data ${ }^{1}$. Studies of birds, important in environmental issues, may spearhead the development of networked databases ${ }^{2}$. But discussions at this year's meeting of the American Ornithologists' Union in August offered a sobering assessment. Widespread participation by curatorial staff and researchers is required for a networked system to succeed, and several issues prevent this.

Perhaps $50 \%$ of specimens in North America have yet to be computerized, and proofreading lags far behind. Quality is an issue when releasing error-ridden data sets to point-and-click users who have little familiarity with the biases and errors in collections. Electronic users are unlikely to check data against specimens, the primary data source. Invoking 'downstream' quality control is not comforting, because peer review is a poor safety net rarely applied to reports and management plans.

Systematics collections are underfund$\mathrm{ed}^{3}$, and the community disapproves of mining collections data while this is the case. Most data-sharing initiatives ${ }^{1}$ overlook this. The value of the data is recognized, so the enterprise producing them must be supported. The resource is also dated, on average reflecting environmental conditions of the $1920 \mathrm{~s}^{4}$. Recent specimens and their data comprise the 'active zone', representing continuing activities to fill knowledge gaps in a changing world. Intellectual-property rights and institutional investments are concentrated here, as are the data most relevant to environmental management efforts. These data will not be widely accessible until bought and paid for. The solution is to renew support (in funding and permits) for fieldwork.

A two-step process towards networked databases may be acceptable. First, old data would be made available. Second, increased support would purchase access to the critical 'active zone'. Another viewpoint wants this support up front: commissioned biodiversity studies or subscriptions would generate new data and leverage access to the old.

The Freedom of Information Act causes concern in the United States ${ }^{5}$ because these databases are usually both public and private. But this act does uphold core values $^{6}$. Data filters can protect vulnerable populations, intellectual-property rights, and rights to privacy.

The collections community is noted for sharing data, but leaving the tap on unminded may be an abrogation of responsibility. Progress on these issues, producing a model eliciting enthusiastic participation, is needed to fully access the wealth of data in natural history collections.

Kevin Winker

University of Alaska Museum,
907 Yukon Drive, Fairbanks, Alaska 99775, USA

1. Association of Systematics Collections Newsletter 27 (3-4), 1-23 (1999)

2. Kaiser, J. Science 284, 888 (1999).

3. PCAST Teaming with Life www.whitehouse.gov/WH/EOP/ OSTP/NSTC/PCAST/pcast.html

4. Winker, K. Conserv. Biol. 10, 703-707 (1996).

5. Cohen, L. R. \& Hahn, R. W. Science 285, 535-536 (1999).

6. Goldwater, W. H. Science 282, 1823 (1998).

\section{Para-political force in attack on science}

Sir - The Commentary by Benny Haerlin and Doug Parr, leading members of Greenpeace, is an insult to science and to the scientists who carry out their daily work on the basis of the scientific ethos (Nature 400, 499; 1999). Greenpeace is a para-political force, and one cannot expect that its activists will appreciate the inherent value system of the scientific enterprise. It is hardly qualified to advise on how to restore public trust in science.

Integration of academic research into industrial innovation does not necessarily imply that scientists lose their intellectual and moral independence. However, my colleagues and I agree with Greenpeace that academic research in the pursuit of truth requires freedom from commercial competition. I have enjoyed this freedom all mylife.

In my experience as a science adviser to the government, dialogue with Greenpeace is difficult or impossible because its activists are not willing to accept scientific standards as the basis of communication. Haerlin and Parr also imply that the attitude of scientific institutions in demanding proof to justify an assertion or 'preventive action' is not acceptable to Greenpeace.

But this does not matter since the organization's goal is not scientific truth or neutral technology assessment but to sow mistrust in science and technology. Greenpeace has performed admirably in this regard. I agree with Haerlin and Parr that the prejudices firmly established in public opinion in Europe cannot, at present at least, be overcome by means of any sciencebased technology assessment. Over many years Greenpeace has contributed to the build-up of distrust between the scientific community and the public. It has undermined the credibility of scientists in assessing technologies.

I thought that Nature was devoted to the advancement of scientific thinking and practice. This hypocritical Commentary is clearly not intended to support the scientific community in its efforts to contribute to a higher degree of rationality and to a better world. The article is an attempt to further undermine the public prestige of science. H. Mohr

University of Freiburg,

Schänzlestrasse 1, D-79104 Freiburg, Germany 